\title{
The Identification of Local Science Learning Resources of Nusa Tenggara Timur for Developing Physics Instructions in High School
}

\author{
Imelda Paulina Soko \\ Student of Science Education Department \\ SPs Universitas Pendidikan Indonesia \\ Bandung, Indonesia \\ imeldapaulina2013@gmail.com \\ Ari Widodo \\ Lecturer of Science Education Department \\ SPs Universitas Pendidikan Indonesia \\ Bandung, Indonesia
}

\author{
Agus Setiawan \\ Lecturer of Mechanical Engineering Department \\ Universitas Pendidikan Indonesia \\ Bandung, Indonesia
}

\author{
Sri Redjeki \\ Lecturer of Science Education Department \\ SPs Universitas Pendidikan Indonesia \\ Bandung, Indonesia
}

\begin{abstract}
This ethnographic study attempts to explore and identify the elements or cultural phenomena that can be integrated in physics learning and introduce students to the cultural values of daily life that are aligned with physics concepts. Culture based approach of contextual learning activities allows students to (1) construct the contextual meaning, values, and knowledge builds upon their prior knowledge and experiences as members of cultural society, (2) increase their engagement in learning so they can construct the knowledge themselves, (3) undertake their own exploratory projects to investigate some aspects of culture or local science that interests them, (4) be motivated to learn physics by their own curiosity. The identification results of NTT traditional culture that can be integrated into physics instruction included the system of livelihood, technology and equipment, and arts, such as (1) the traditional systems of units and measurement, (2) Newton's Law and its application in Pasola, traditional umbrella dance Enene, traditional house Ammu Hawu, (3) temperature, heat and heat transfer concepts in Tatobi, the cone-shaped roof function of Mbaru Niang, the making of Moke process, (4) work and energy in stone-dragging ceremony of Sumbanese megalithic royal gravestones Tena watu, Patar alu dance, (5) sound and waves concepts in Sasando, Kediding and Foy Pay, and so on. For Physics teachers to do this well, they must (1) be knowledgeable about the nature of Physics, (2) develop their own observational and exploratory skills of balancing local science with modern science.
\end{abstract}

Keywords-local science, learning resources, physics instruction, ethnographic

\section{INTRODUCTION}

Physics is an instruction that explains and provides the ability to analyze (whether qualitatively or quantitatively) the phenomena and process of the nature, the characteristic of every single substance and their implementation in daily life. The implementation of physics based on the nature of science will generate students who do not simply master the physics concepts or be academically intelligent, but also encompass themselves with scientific attitude that enable them to see the world objectively as well as make a right decision toward science application. The implementation of physics is students center oriented learning, but the teacher's professional role here becomes the one that determines the succeed of the learning process through learning strategies or models. The development of learning situation which the students are fully motivated to learn can be take place if the teacher is professionally able to design the learning activity that support all of the learning process.

One of the problems that faced by the future teachers or even senior teachers is how to modify a theoretic physics material into an easy to understand, valuable, and properly fit the students daily experience material. A research showed that concept understanding and the ability of Senior High School students in Kupang in analyzing tables, figures, and graphs related to physical phenomena is low [1]. Based on result of the pre-study interview with one of the physics teachers in Kupang, physics instruction is done by utilize various teaching and learning strategies, but still the students find it difficult to understand the physics concept. Some studies suggest designing contextual learning by illustrating some problems faced in the students' daily experiences [2][3][4][5]. Teaching and learning design which referred to cultural approach i.e. Nusa Tenggara Timur (NTT), is expected to increase the students participation in teaching and learning process, so the students themselves who will create the knowledge, they will be motivated in learning Physics as well, and eventually they will eagerly learn physics without other's force. The teaching and learning activity should be designed by the teacher him/herself, that is why the teachers have to be provided with knowledge and competency of developing teaching and 
learning activity with cultural approach through teachers training and education.

NTT as one of the provinces in Indonesia is rich in the context of traditional culture, such as house, art, woven cloth, ritual ceremonies, different beliefs about natural phenomena, and many more. These kinds of wealth are not only representing the traditional culture which inherited from one generation to the other, but also depict the richness of values and views of life that hold by the people in NTT. These cultural wealth are also full of moral and educational values, which represented by the houses structures, carve pattern, traditional music instruments, the village structures, traditional organizations, people's habit, and many more. In Timor island for instance, women who just born a baby are usually occupied in a room with fireplace. This is relevant with the concept of temperature, heat and its transfer in physics. Another example comes from Sumba Barat Daya, where Pasola is held. This is a fighting game between two groups of cavalry that throw spears each other in savanna. Ritual of throwing the sola to the rival while riding a horse is related to the concept of particles movement dynamics. However, the culture of NTT which full of educational values is just a certain group wealth and not a part of education which should be contextual. This is not a good condition, but it might become a good potential in increasing the quality of teaching and learning through cultural integration in teaching and learning, particularly in Physics.

Since Science is a subculture in western countries, teaching Science in Indonesia by adapting Western culture will affect clash and conflict to the students [6]. Students' basic knowledge really influences the formation of a new concept. The students grow in the world and surrounded by other people so social interaction indeed plays it influence toward what the students do, think and the way they think of something [7]. Cultural background has more influence toward Science teaching and learning than a subject matter content [8], thus, science teaching and learning with ethnoscience approach is indeed need in order to create the balance of modern and local Science. The cultural wealth of NTT has educational value that can be integrated into science learning activities; contextual learning. In order to develop culture-based physics learning activities, we need to identify the elements, values and cultural phenomena that can be used as learning sources in physics learning activities.

Culture strongly influences how an individual approaches education, and a society's culture determines how that society educates its citizens. Education with the cultural approach is very proper for plural civilized country like Indonesia. Today's paradigm of education is balancing intellect development (academic intelligence), emotions, and spirit, to develop cultural values education. In order to reach that goal, we need to assess and develop ethnopedagogy as culturalbased approach, in the context of Indonesian culture. The ethnopedagogy approach in science education can harmonize modern science (Western science) and local science (indigenous science) are inherited, and it has the ability to uncover scientific concepts contained in the original Science, tradition and local wisdom firmly held by certain cultural groups. The scientific concepts disclosure through the study of knowledge possessed by a particular cultural group is known as ethnoscience.

The aim of this research is generating local content learning culture based chemical Sea People that can improve the mastery of concepts, cultural knowledge and generic skills Science of junior high school students. In a university community service program "Training for Creating Balinese Culture-based Learning Tools for Junior High School Science Teachers of Buleleng", developed seminars and training of the making of Balinese culture-based chemistry learning tools. Overall, a review of the literature and some researches suggests that advisedly designed culture-based physics instruction helped students to students harmonize school science with their local culture as their prior knowledge and empowered teachers to contextualize physics instruction and to teach in ways that support diverse learners. The exploration and identification of local science phenomenon or elements is the first and important step to achieve those purposes [9].

Cobers [10] looked at the teaching of science as cultural transmission and cultural domination for students. The term culture refers to a system or arrangement of symbols and meanings that apply to social interaction in the community [11]. Based on this limitation, Science can be seen as a subculture of western culture, and science from the west (western science) is a sub culture of Science. From the viewpoint of cultural anthropology, to learn science is to acquire the culture of science; students must travel from their everyday life-world to the world of science found in their science classroom.

Students or individuals who engage in cross-cultural influenced by cultural group identities [12]. J.A Banks [12] identified six stages of ethnic identity: 1) ethnic psychological captivity, 2) ethnic encapsulation, 3) ethnic identity clarification, 4) biethnicity, 5) multiethnicity/ reflective nationalism, and 6) global competency, This individual recognizes that the ethical values of humankind is oblivious to race and ethnicity.

Physics today tend to be studied as a memorizing of products, concepts, theories and laws. An attempt to teach physics concepts to the students to be more contextual by reviewing the concepts and showing its application in technology, phenomena in their daily lives. Teachers can implement this culture-based and contextual teaching by directly engage and motivate students to prove what values they can take from learning activities through character education. If we failed in building students' good character and personality in early childhood education then it will give a negative impact of setting young children on a trajectory of success. Thus, it is necessary to motivate all educators, especially school teachers to deliver culture-based and contextual learning in preparing human's excellent characters.

In order to implement culture-based physics learning, teachers should follow these principles:

\section{A. Teachers need to identify students' prior knowledge of the} local science.

Early identification of students' knowledge about their local science aims to explore the students' thoughts in order to accommodate the concepts, principles or beliefs of 
the students. It is important to remember that every child will have their own perspectives or conceptions to an object, event or phenomenon. The important thing to do before learning is teachers should find out what students already knew [18].

B. Learning in groups.

Traditional societies tend to voluntarily and informally do activities in groups. Group learning is the basic form to characterize their learning. Reference [19] found that learning in a group is an education unit that is indigenous (native), as the learners' agreement to learn by themselves or inviting 'instructor' from other groups.

\section{Teachers as skilled and wise negotiator}

In physics learning process, a teacher holds a central role as the negotiator of western science and local culture/science with his/her students. Teachers make decisions based practical pedagogy knowledge, so they should be able to integrate a holistic principles of culture, values, and worldview. Physics teachers need to be smart and wise in negotiation.

Furthermore, learning science can also be carried out with due regard to the following matters; (1) presents a list of problems to be discussed by students, (2) science skill process is a very important process of teaching and learning, (3) teachers need to promoting communication among the students in order to build an inquiry and problem solving skills, (4) using local culture environment as learning sources [15].

\section{METHODS}

This research was an ethnographic study with an interpretive design. There are three modes of data collection in this study: observation, interviewing and archival research. Four cultural experts and three elders of NTT were interviewed throughout their knowing, wisdom, and erudition of local culture. 24 physics teachers in Kota Kupang and Kabupaten Ende were involved to identify the values of NTT local culture. An open-ended questionnaire of ethnoscience in NTT local culture and an interview question guide of NTT local values were use as research instruments. The following research questions guided the study: 1) What kind of knowledge systems, language form, and the social system of NTT local culture do relevant to modern science? 2) How do teachers integrate systems of knowledge, language form, and the social system of NTT local culture as learning resources into physics instruction?

\section{RESULT AND DISCUSSION}

NTT consists of a diverse group of various cultures and they populate the expanse of NTT archipelago. Those various ethnic groups produce a variety of cultures, local languages, folk dance, social order system, the traditional government, and others. Although there are the difference between ethnic groups, people of NTT still has a similarity in their characteristics. Those characteristics resulted from the ancestors traditional beliefs. The traditional beliefs of NTT ancestors regard to man's spiritual relationship with God, community, and nature. According to history, the ancestors guidance derived from God through the elected ancestors, who then delivered the guidance and beliefs orally and hereditary [22]. For NTT ethnic groups, oral tradition is linked to their way of life. Traditional beliefs of NTT become guidance in social life. NTT is a heterogeneous province but the people live together in a peaceful coexistence life.

\section{A. The Values of Nusa Tenggara Timur Local Culture That Can be Integrated into Physics Instruction}

NTT has a unique traditional culture and we can notice the difference between every ethnic groups. The differences can be in languages (dialects), motif of customs (sarongs), the styles or the architectures of arts, houses and so on. There are educational values in local cultures of NTT that can be integrated into learning activities. This certainly can support contextual learning. Here are the identification results of NTT traditional culture that can be integrated into physics instruction:

\section{1) The traditional systems of units and measurement}

The traditional Endenese use moso: finger, repa: fathom, paga: span, and baga: step, as the units of length. The traditional Sikkanese use repa; span, wati: step, a'a: fathom, as the units of length. The Alornese use can to measure their harvest such as rice, corn and beans. For length measurement, they use bamboo segment and fathom as the units of length. The traditional Manggarainese use pagat: span, depa: fathom, pa: step, lampa: leap, as the length units, and they also use tongka and cewak as measuring instrument and the units of mass. Tongka and cewak also can be converted to other traditional systems of mass unit, such as;
a. 1 bahi
$=0,5$ tongka
$=2,5 \mathrm{~kg}$
b. 1 roto ci'e
$=2$ tongka
$=10 \mathrm{~kg}$
c. 1 warang
$=4$ tongka
$=20 \mathrm{~kg}$
d. 1 wega
$=8$ tongka
$=40 \mathrm{~kg}$
e. 1 beka
$=16$ tongka
$=80 \mathrm{~kg}$

The traditional Manggarainese still use moso to develop and divide their Lingko cara, the round, spider-web structure rice fields.

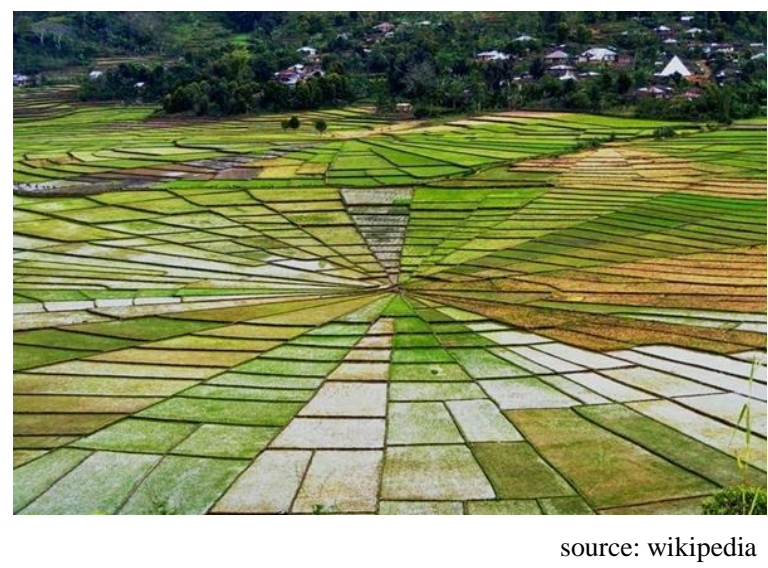

Fig. 1. The division of Lingko cara spider web rice fields is primarily used traditional measurement

\section{2) Newton's Laws and its applications}

- Pasola is a thanksgiving ceremony to ancestral spirit of people from West Sumba. Pasola is a ritual war festival by two groups of selected Sumbanese men; they riding 
their horses fling wooden spears (sola) at each other. This game requires a high skill at horse riding and spear throwing. Pasola accords to the concept of the dynamics of particle motion. The motion of sola thrown is associated with the cause of motion, like initial velocity of the running horses.

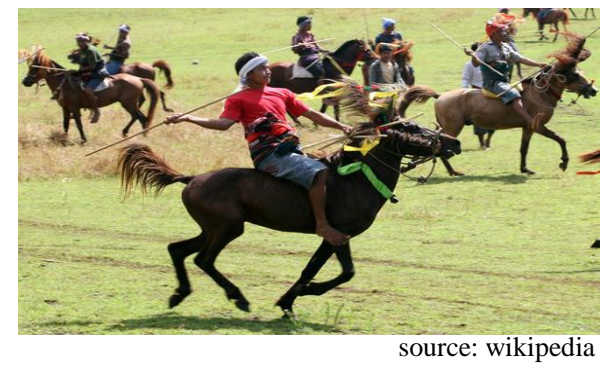

Fig. 2. The Pasola is an example of dynamics of particle motion

- The Alornese still use bows and arrows for hunting tools and war. Teachers can explain the iple of the bow and arrow using the action-reaction law.

- Kela Koti or traditional spinning top of Endenese has the rhombus shaped with hibiscus rope wrapped around the neck of it. The concept of rotation can be applied in this traditional game.

- The traditional umbrella dance Enene, is a welcoming dance from Lamaholot ethnic group, East Flores. Enene requires skills to rotate the umbrella. The dance aesthetics can be explained by using the concept of rotational motion and rotation of rigid body equilibrium.

- The timber panels of traditional house Ammu Hawu (traditional house of Sabunese) are not placed/planted into the ground but deliberately resting on a rock. The meeting point of the panels and rocks causing friction force. Friction force is determined by the coefficient of friction and the normal force.
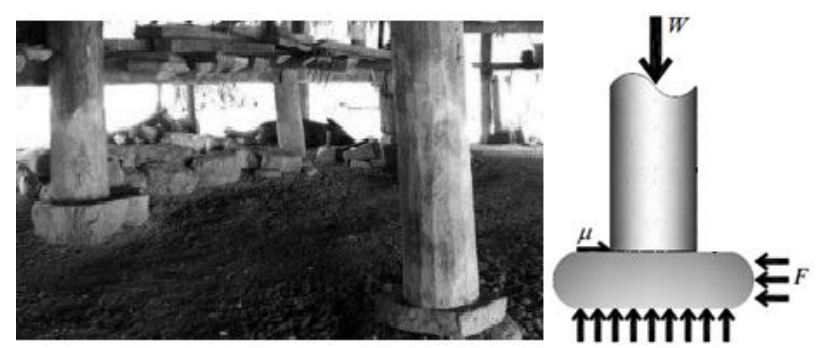

source: wikipedia

Fig. 3. The timber panels of Ammu hawu placed on rocks

\section{3) Temperature, Heat and Heat Transfer}

- Tatobi is a series of activities aimed to warm postpartum mother in rooms where there is a fireplace. Tatobi is a smoke tradition to support the recovery process and maintain the physical condition as it was before pregnancy. This traditional ritual is relevant to the concept of temperature, heat, and heat transfer in physics.

- Mbaru Niang is a traditional house of Wae Rebo village, located within the rainforest mountains of Flores. The higher mountainous area surrounding Wae Rebo is often wrapped in fog and cloud with extremely cold temperatures. Mbaru Niang consists of 5 floors with a height of about $15 \mathrm{~m}$, with a coneshaped roof. The cone-shaped roof function of Mbaru Niang can be assessed by heat transfer.
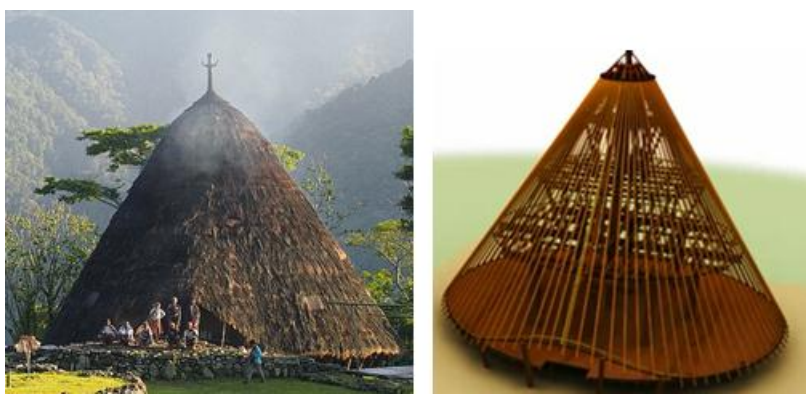

source: wikipedia

Fig. 4. Mbaru Niang traditional house is an example of heat transfer

- During the cooking water, the mother often adding a spoon or other small-sized iron made into a container of cooking water to faster boiling process.

- Moke is a traditional beverage, symbol of brotherhood and unity of Ngadanese. Moke is a traditional drink made of made of Borassus flabellifer and Arenga pinnata fruits fermentation, this beverage is made traditionally which involves techniques taught from generations to generations. The concept of temperature, heat, and heat transfer is closely related to the process of making this Moke.

4) Work and Energy

- The traditional way of moving large stones for tombs of Sumbanese is known as tena watu. This tena watu use work and energy concepts, especially simple machine. The stone is estimated to weight 40-70 tons and measure $5 \times 4 \times 1 \mathrm{~m}$. Stone slabs are usually made at a location farther away from the final location (traditional villages) which is generally located on the hilltop.

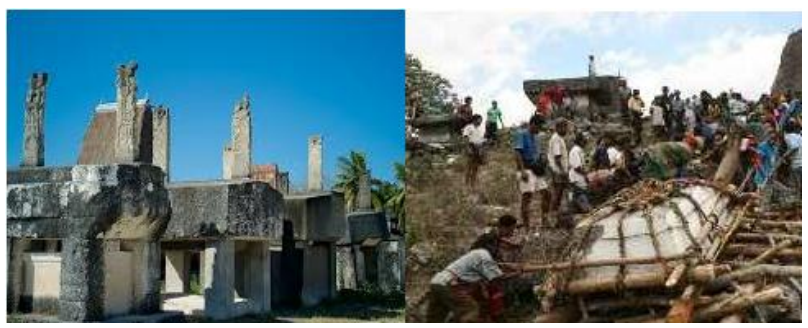

source: wikipedia

Fig. 5. Work and energy concepts in stone-dragging ceremony of Sumbanese megalithic royal gravestones 
- The dancers movements on traditional dance of Sikkanese Patar alu, can be explained by using rigid body equilibrium concept. The dancers climb and lay on a standing stick standing, with a balanced position by continuing to spin.

\section{5) Sound waves}

Sasando is a traditional music string instrument from Rote island. The main part of the Sasando is a bamboo tube that serves as the frame of the instrument. Surrounding the tube are several wooden pieces serving as wedges where the strings are stretched from the top to the bottom. The function of the wedges is to hold the strings higher than the tube surface as well as to produce various length of strings to create different musical notations. Traditional music instrument Foy Pay comes from Ngada. Foy Doa is a double flute of small bamboo.

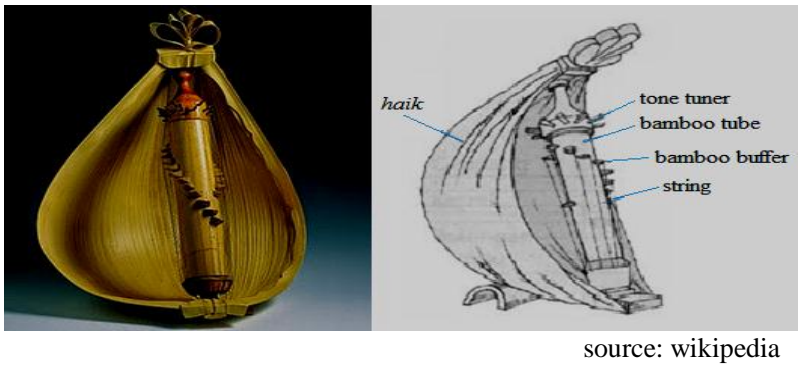

Fig. 6. Sasando traditional music instrument

\section{6) The Integration of Nusa Tenggara Timur Local Culture} into Physics Instruction

Before the integration, teachers should analyze, elaborate, and develop the physics concepts in those local science elements. The development of a culture-based physics instruction requires teachers to understand the nature of physics, so they can construct a process, product, and skill oriented physics instruction. The teachers also must develop their own observational and exploratory skills of balancing local science with modern science. To help teachers develop a culture-based physics instruction, teachers should notice these following points; (1) to provide meaningful science programs for students in traditional settings is that of contrasting conventional science as taught in schools with the knowledge/beliefs/skills in traditional settings, (2) to present examples of incongruity or miracle (discrepant event) to the students which is actually commonplace in scientific concept, (3) to encourage students to ask question and participate actively, (4) to encourage students to make a series of schemes on a concept developed during the learning [21].

Local cultures of NTT have educational values that can be integrated into learning activities. The integration of local science concepts into physics instruction helps teachers and students to learn more and better. The culture-based physics instruction interact students to honor their nature and culture. If students' beliefs are in accordance with the concept of physics, there will be interference mutually reinforcing (secured collateral learning). A teacher is required to understand and have sufficient skills in developing various models of effective, creative and fun learning. If the teachers have been able to grasp the concept or the basic theory of learning which refers to the process (along with the concepts and theories) learning as described above, then the teachers can creatively develop a distinctive learning model, based on the real conditions in each workplace, which in turn will appear learning models version of the teacher concerned, which is certainly the more enriched learning models that already exist. The integration of culture and science in culturebased physics instruction hopefully can help students understand physics as modern science through contextual learning activities and based on the culture as students prior knowledge.

\section{CONCLUSIONS}

Teachers' efforts to teach science contextually can be enhanced by reviewing the concepts and showing its application in technology and students daily lives. Culturebased physics instruction is a planned and conscious attempt through the exploration and identification of the local culture potential wisely to create learning process and environment. In culture-based physics instruction students can develop their potential to achieve skills, knowledge and attitudes as Indonesian. We can simply define culture-based physics instruction in high school as a learning program in accordance with local needs, by utilizing a variety of natural resources, human resources, geographic, cultural, historical and potential of other areas that are useful in the process of competence development in accordance with the potential, talents and interests of students. The specificity of principles, customs, beliefs, views of nature, and daily live experiments which is different in each ethnic group, is potential to be integrated in physics instruction. The integration of local culture into physics instruction can help students understand physics as modern science based on their prior knowledge through a contextual and culture-based learning. The specificity of principles, customs, beliefs, views on natural phenomena and events in everyday life with unique features and even different in each cultural group, potentially to be integrated in physics learning. The integration is expected to help students comprehend physics as modern science through contextual learning activities and grounded in the culture as prior knowledge of the students.

\section{Acknowledgment}

We would like to thank all culture experts, elders of NTT and senior high school physics teachers of Kota Kupang and Kabupaten Ende who participated in this study. Research was supported by the Dinas PPO and MGMP Kabupaten Ende.

\section{References}

[1] M. N. Lete, "Identifikasi pemahaman konsep dan kemampuan siswa dalam menganalisis tabel, gambar, dan grafik berkaitan dengan fenomena fisis siswa sekolah menengah atas se-kota Kupang", (Thesis). Universitas Nusa Cendana, Kupang, 2012

[2] M. Skoumis, and V. Hatzinikita, "Learning and Justification during a Science Teaching Sequence", The International Journal of Learning Vol. 16, No. 4, 2009, p. 327-342.

[3] J. Guisasola, J. M. Almudi, M. Ceberio, and J. L. Zubimendi, "Designing and evaluating research-based instructional sequences for introducing magnetic fields", International Journal of Science and Mathematics Education No.7, 2009, p. 699-722. 
[4] M. I. Hernández, D. Couso, and R. Pintó, "The analysis of students' conceptions as a support for designing a teaching/learning sequence on the acoustic properties of materials", Science Educational \& Technolology Journal, Vol. 21, 2011, p. 702-712.

[5] A. Loukomies, D. Pnevmatikos, J. Lavonen, A. Spyrtou, R. Byman, P. Kariotoglou, and K. Juuti, "Promoting students' interest \& motivation towards science learning: the role of personal needs \& motivation orientations", Res. in Science Education. 43(6), 2013, p. 2517-2539.

[6] O. J. Jegede, "Collateral learning and the eco-cultural paradigm in science and mathematics education in Africa", Studies in Science Education, (25), 1995, p. 97-137.

[7] R. S. Siegler, and M. W. Alibali, "Children's thinking, 4th ed", Upper Saddle River, NJ: Prentice Hall, 2005.

[8] D. Baker, and P. C. S. Taylor, "The effect of culture on the learning of science in non-western countries: The results of an integrated research review", International Journal of Science Education, 17, 1995, p. 695704.

[9] W. W. Cobern, and G. S. Aikenhead, "Cultural aspects of learning science", In K. Tobin \& B. Fraser, Eds. International handbook of science education. Dordrecht, The Netherlands: Kluwer Academic Publishers. 1996.

[10] Geertz, C. (1973). The interpretation of cultures. New York: Basic Books.

[11] J. A. Banks, "Multiethnic education: Theory and practice", Newton, MA: Allyn and Bacon. 1988..

[12] D. Ausubel, J. Novak, and H. Hanesian, "Educational psychology, A cognitive view (2nd ed)", New York: Holt, Rinehart \& Winston, 1968.

[13] Supriyono. "Pemberdayaan Warga Belajar pada Kelompok Belajar (Studi Pengembangan Model Pengelolaan Program Pembelajaran Paket B Kesetaraan Melalui Kelompok Belajar", (Disertation), Sekolah Pascasarjana, Universitas Pendidikan Indonesia, Bandung, 2000

[14] G. Haukoos, and D. LeBeau, "Inservice activity that emphasizes the importance of the cultural in teaching school Science", Journal of American Indian Education-Arizona State University. 32(1). 1992.

[15] J. J. Djeki, and Istiasih, "Pengkajian nilai-nilai luhur budaya spiritual bangsa propinsi Nusa tenggara Timur", Jakarta: Departemen Pendidikan dan Kebudayaan. 1992 